\title{
Potential Use of Green Alga Ulva sp. for Papermaking
}

\author{
Ana Moral,,${ }^{\mathrm{a} *}$ Roberto Aguado, ${ }^{\mathrm{a}}$ Rocío Castelló, ${ }^{\mathrm{a}}$ Antonio Tijero, ${ }^{\mathrm{b}}$ and Menta Ballesteros ${ }^{\mathrm{a}}$
}

The large amount of cellulose found in Ulva sp. and its low percentage of lignin-like compounds make it an interesting raw material for partially substituting wood pulp to produce pulp and paper. This work shows the suitability of mild chemical treatments for papermaking using residual biomass from this green seaweed, harvested on the beaches, in order to give it added value. A chemical characterization was used to determine ethanol-benzene, hot water, and $1 \%$ soda extractives, ash content, holocellulose, $\alpha$-cellulose, and acid-insoluble material. Cellulose extraction was performed with low proportions of soda and hydrogen peroxide, and it was subjected to a refining step. A design of experiments was used to explain the influence of soda $(6 \%, 8 \%$, and $10 \%)$ and hydrogen peroxide $(2 \%, 4 \%$, and $6 \%)$ based on oven-dry weight, plus refining (1000 PFI revolutions, $3000 \mathrm{PFI}$ revolutions, and $5000 \mathrm{PFI}$ revolutions). The results showed that to attain good paper strength, it is advisable to operate at maximum alkali charge, minimum peroxide concentration, and refine to a high degree.

Keywords: Ulva sp.; Green algae; Pulping; Refining; Hydrogen peroxide; Sodium hydroxide

Contact information: a: ECOWAL group, Molecular Biology and Biochemical Engineering Dpt., Experimental Sciences Faculty, Pablo de Olavide University. Ctra. de Utrera km 1, 41013 Seville, Spain; b: Chemical Engineering Dpt., Faculty of Chemistry, Complutense University of Madrid. Av. Complutense s/n, 28040 Madrid, Spain; *Corresponding author: amoram@upo.es

\section{INTRODUCTION}

Currently, there is increased interest in producing paper from seaweed. To a large extent, the potential use of seaweed is motivated by the clear advantages that they present with respect to terrestrial biomass, such as their very low or null lignin content and rapid growth. The cellulose contents are close to those of conventional fiber sources, which gives them great importance for their use in obtaining paper (Knoshaug et al. 2013). Numerous benefits have been reported from seaweed's use in papermaking, as it avoids the dependence on tree monocultures and the variability of the price of wood sources, which is expected to increase over time. Furthermore, it involves low consumption of chemical reagents due to its easy treatment, valorization of coastal waste associated with environmental and economic problems in tourist areas, and higher productivity of biomass than non-fertilized crops (Rajkumar et al. 2014; Baweja et al. 2016). It has certain drawbacks such as the difficulty in removing salts, inorganic compounds, and other residues. This can make the production process expensive. In some cases, the sheets of paper made from seaweed have poor mechanical properties (Ververis et al. 2007; Khiari et al. 2010).

A wide variety of algae have been used to obtain paper with different pulping treatments with a low environmental impact (Knoshaug et al. 2013). You and Park (2004) patented a method for producing paper from Rhodophytae by immersing the algae in an alcohol-based extraction solvent followed by boiling. The extraction can be carried out without chemicals at $120{ }^{\circ} \mathrm{C}$ to $140{ }^{\circ} \mathrm{C}$ for Gelidialian sp. (Seo et al. 2010), or with $2 \%$ 
$\mathrm{NaOH}$ at $100{ }^{\circ} \mathrm{C}$ in the case of Gracilaria verrucosa (Laksitoresmi et al. 2010). Pulp and paper have been obtained using green algae, requiring low doses of soda and temperatures around $100{ }^{\circ} \mathrm{C}$ for Chaetomorpha sp. (Kiran et al. 1980) or Rhizoclonium sp. (Chao et al. 2000). Nicolucci et al. $(1995,1996)$ explained a simple physical treatment that reduces the particle size followed by a chemical treatment at $70{ }^{\circ} \mathrm{C}$ with soda and hydrogen peroxide in low concentrations to obtain paper from a mixture of green and red algae (Ulva rigida, Ulva lactuta, Enteromorpha instestinalis, and Gracilaria confervoides). However, to the best of the authors' knowledge, the green algae Ulva has not been used alone for papermaking by environmentally sustainable methods.

Green algae are promising raw materials for papermaking as they are known to contain more cellulose than brown or red algae (Baweja et al. 2016; Jmel et al. 2016). Moreover, they are a good source of dietary fiber and other important nutrients such as amino acids and polyunsaturated fatty acids, comparable to fruits and vegetables. The possibility of using Ulva pertusa as feedstock for biofuel (Choi et al. 2013; Kim and Ha 2015; Michalak 2018) and for the bioproduction of D- glucaric acid and succinic acid has been established (Lee et al. 2014). U. prolifera has been investigated for bioethanol production using a pretreatment with hydrogen peroxide and enzymatic hydrolysis (Li et al. 2016), and Ulva lactuca has been valorized by the extraction of insoluble fiber and soluble dietary fiber (Yaich et al. 2011). Cellulose extracted from green seaweed Ulva fasciata was processed to synthesize biodegradable carboxymethyl cellulose films with applications in the cosmetic, food, textile, medical, agricultural, and pharmaceutical industries (Lakshmi et al. 2016). Likewise, cellulose from Cladophora sp. algae has been proposed to prepare a conducting polypyrrole-based composite material (Mihranyan et al. 2008; Olsson et al. 2012) for use in ion exchange membranes or sensors.

In this work, the main objective was to obtain a product that resembles the characteristics of conventional paper using the green algae Ulva sp. as a source of cellulose fiber, together with conventional softwood kraft fibers $(50 \%)$. This approach has been chosen by other authors (Seo et al. 2010), and it improves inter-fiber bonding because the size and shape of algal fibers might be too homogeneous. A mild chemical treatment with low-polluting reagents (soda and hydrogen peroxide) was optimized by following a central composite experimental design. A chemical characterization of Ulva sp. waste was conducted to determine its potential for pulp and paper production. Finally, mechanical and optical tests of the paper sheets were performed, and the effects of the ratio of soda to dry material, the ratio of hydrogen peroxide to dry material, and refining were studied.

\section{EXPERIMENTAL}

\section{Materials}

Ulva sp. from tidal waste was harvested by hand at "Punta Entinas-Sabinar" (Almería, Spain) in September 2017. Samples were washed with freshwater, screened to remove sand and other impurities, and dried at $40{ }^{\circ} \mathrm{C}$ for 3 days. Diethylenetriaminepentaacetic acid (DTPA) and anthraquinone were supplied by Sigma-Aldrich (Madrid, Spain). Anhydrous $\mathrm{MgSO}_{4}, \mathrm{NaOH}$ pellets, and hydrogen peroxide were purchased from PanReac (Barcelona, Spain).

\section{Cellulose Extraction}

Ulva sp. was cooked in a $15 \mathrm{~L}$ batch cylindrical reactor with $\mathrm{NaOH}(6 \%, 8 \%$, and $10 \%), \mathrm{MgSO}_{4}(0.2 \%)$, and anthraquinone $(1 \%)$ at $90{ }^{\circ} \mathrm{C}$ for $60 \mathrm{~min}$, adding water to achieve 
a liquid-to-solid ratio of 9 . It should be noted that the percentages express the weight ratio of reagent to oven-dry raw material, not to the solution.

The resulting pulps were treated with hydrogen peroxide $(2 \%, 4 \%$, and $6 \%$, based on oven-dry pulp weight) and 0.5\% DTPA (Abdel-Halim and Al-Deyab 2013). Each sample was placed in a polyethylene bag and immersed in a thermostatic bath at $60{ }^{\circ} \mathrm{C}$ for 60 min. Finally, samples were dried at $40{ }^{\circ} \mathrm{C}$ for one week.

\section{Refining}

Cellulose pulps were beaten at $10 \%$ consistency in a Metrotec PFI mill (Lezo, Spain). The numbers of revolutions applied were 1000, 3000, and 5000. The electric power of the engine was $0.37 \mathrm{~kW}$ as the voltage applied was $220 \mathrm{~V}$. The degree of refining, expressed as freeness, was measured using a Canadian Standard Freeness (CSF) tester (West Berlin, NJ, USA), following TAPPI T227 om-17 (2017).

\section{Chemical Characterization of the Samples}

The pulp obtained was characterized chemically in accordance with the common TAPPI test methods for raw materials and/or pulps (TAPPI 2019), beginning with T264 cm-07 (2007) for the preparation of samples for chemical analysis. The standard T203 cm09 (2009) was followed to estimate the content of alpha-cellulose, understood as the fraction that is resistant to consecutive treatments with $17.5 \%$ and $9.45 \% \mathrm{NaOH}$ solutions, after a chlorite delignification was performed to measure the holocellulose content (Ahlgren and Goring 1971). According to T222 om-15 (2015), the determination of acidinsoluble Klason lignin was carried out with $\mathrm{H}_{2} \mathrm{SO}_{4} 24 \mathrm{~N}$. Solid-liquid extractions followed T204 cm-17 (2017) for ethanol-benzene extractives and T207 cm-08 (2008) for hot water solubility, while the ash content was determined by means of a muffle furnace in accordance with T211 sp-11 (2011).

\section{Sheet Forming and Testing}

Ten isotropic handsheets were made from each of the Ulva sp. samples, always mixed with an unbleached pine kraft pulp (PKP) in a 1:1 weight ratio. The PKP, reportedly obtained from the wood of Pinus pinaster Ait., was of industrial origin. In any case, a laboratory sheet former conforming to the ISO standard 5269-1 (2005) was used. Agitation was done by hand, with a standard stirrer. Couch weights and standard plates were used to collect the handsheets. Sheets were left at $23{ }^{\circ} \mathrm{C}$ and $50 \% \mathrm{RH}$, while pressed by drying rings, for $24 \mathrm{~h}$. The basis weight was $60 \mathrm{~g} / \mathrm{m}^{-2}$.

The tensile test for the breaking length and stretch, the burst test, and the tear test were performed by means of appropriate testing machines from Hounsfield, Metrotec and Messmer, respectively, and in accordance to the ISO standards 1924 (1992), 1974 (2012), and 2758 (2014). Brightness was determined by means of a spectrophotometer from Lorentzen \& Wettre (Kista, Sweden), following ISO 2470 (2009).

\section{Experimental Design}

In order to evaluate the influence of three independent variables (alkali dose, hydrogen peroxide concentration and refining) on the physical properties of sheets, a central composite design with response surface methodology was chosen as the approach (Abd Hamid et al. 2014). This experimental design consisted of 15 tests that were used to estimate the quadratic terms of a polynomial model (Table 1). The values of the independent variables were normalized by using Eq. 1 in order to facilitate the direct 
comparison of coefficients and expose the individual effects of the independent variables on each dependent variable,

$$
X_{n}=2 \frac{X-\bar{X}}{X_{\max }-X_{\min }}
$$

where $X_{n}$ is the normalized value of soda $(S)$, hydrogen peroxide $(P)$, or refining degree $(R) ; X$ is the absolute experimental value of the variable concerned; $\bar{X}$ is the mean of the extreme values; and $X_{\max }$ and $X_{\min }$ are its maximum and minimum value, respectively. The variables values for each test are shown in Table 1.

Table 1. Experimental Design: Sets of Conditions and Normalized Values

\begin{tabular}{|c|c|c|c|c|c|c|}
\hline Assay & $\mathrm{NaOH}(\%)$ & $\mathrm{H}_{2} \mathrm{O}_{2}(\%)$ & $\mathrm{PFI}$ revolutions & $\mathrm{X}_{S}$ & $\mathrm{X}_{\mathrm{P}}$ & $\mathrm{X}_{R}$ \\
\hline 1 & 8 & 4 & 3000 & 0 & 0 & 0 \\
\hline 2 & 10 & 6 & 5000 & 1 & 1 & 1 \\
\hline 3 & 6 & 6 & 5000 & -1 & 1 & 1 \\
\hline 4 & 10 & 6 & 1000 & 1 & 1 & -1 \\
\hline 5 & 6 & 4 & 1000 & -1 & 1 & -1 \\
\hline 6 & 10 & 2 & 5000 & 1 & -1 & 1 \\
\hline 7 & 6 & 2 & 5000 & -1 & -1 & 1 \\
\hline 8 & 10 & 2 & 1000 & 1 & -1 & -1 \\
\hline 9 & 6 & 2 & 1000 & -1 & -1 & -1 \\
\hline 10 & 8 & 6 & 3000 & 0 & 1 & 0 \\
\hline 11 & 8 & 2 & 3000 & 0 & -1 & 0 \\
\hline 12 & 8 & 4 & 5000 & 0 & 0 & 1 \\
\hline 13 & 8 & 4 & 1000 & 0 & 0 & -1 \\
\hline 14 & 10 & 4 & 3000 & 1 & 0 & 0 \\
\hline 15 & 6 & 4 & 3000 & -1 & 0 & 0 \\
\hline
\end{tabular}

Experimental data were fitted to a second-order polynomial model (Eq. 2) which relates each dependent variable (tear index, breaking length, stretch, burst index, and brightness) with the operational variables.

$$
Z=a_{0}+\sum_{i=1}^{n} b_{i} X_{n i}+\sum_{i=1}^{n} c_{i} X_{n i}^{2}+\sum_{i=1 ; j=1}^{n} d_{i j} X_{n i} X_{n j}(i<j)
$$

In Eq. 2, $Z$ and $X_{n i}$ denote dependent and normalized independent variables, respectively, and $a_{0}, b_{i}, c_{i}$, and $d_{i j}$ are constants to be estimated from the experimental data. For three independent variables, the model is presented in Eq. 3,

$$
Z=a_{0}+b_{1} X_{S}+b_{2} X_{P}+b_{3} X_{R}+c_{1} X_{S}^{2}+c_{2} X_{P}^{2}+c_{3} X_{R}^{2}+d_{12} X_{S} X_{P}+d_{13} X_{S} X_{R}+
$$
$d_{23} X_{P} X_{R}$

where $Z$ stands for each of the dependent variables. The software SigmaPlot ${ }^{\circledR}$ (Version 12.0) was used to formulate the models and analyze the data. 


\section{RESULTS AND DISCUSSION}

\section{Chemical Composition of Ulva sp. Waste}

The results of the chemical characterization of Ulva sp. dead biomass, including ethanol-benzene extractives (EBE), hot water and $1 \%$ soda solubilities (HWS and $1 \% \mathrm{SS}$ ), ash, holocellulose (HOL), $\alpha$-cellulose ( $\alpha$-CEL), and acid insoluble material (KLAS), are presented in Table 2. For comparison purposes, chemical composition data from a different green alga, from another non-wood material, and from a conventional raw material for papermaking are shown. The EBE content is very low in typical raw materials for papermaking such as Eucalyptus globulus or Pine pinaster (1.2\% and 2.6\%, respectively; Jiménez et al. 2007), and the values found for this macroalga $(3.8 \% \pm 1.1 \%)$ were close to those in wood. In contrast, HWS and 1\% SS were much higher than those of wood and woody stems (Jiménez et al. 2007), but similar to those of certain grasses (Sharma et al. 2018). This was probably due to the starch fraction (Mukherjee and Keshri 2019). However, the high ash content in Ulva sp. $(19.8 \% \pm 3.1 \%)$ is especially remarkable. This result is comparable with previous studies on Ulva lactuca (19.6\%; Yaich et al. 2011), Ulva pertusa Kjellman (22.5\%; Lee et al. 2014) or other green algae such as Rhizoclonium sp. (15.9\%; Chao et al. 1999). It is clearly low in comparison with brown algae (30 to 40\%; Rupérez 2002). In general, macroalgae are characterized by high ash content and a very large percentage of mineral salts that is much higher than for vascular plants. When algae are collected, they contain sand and carbonated deposits. These impurities are largely eliminated during cleaning, but the residual contaminants contribute to the high percentage of ash. The ash contents in seaweeds are variable, and many factors such as the species or location, collection date, salinity, etc, determine its value (Dawes et al. 1987).

Cellulose, the main component of the cell wall, is more abundant in green algae than in red or brown algae (Kim and Ha 2015; Jmel et al. 2016). In this study, holocellulose was the most abundant fraction in Ulva (Table 2). Yaich et al. (2015) observed that hemicellulose was the main fraction $(32.5 \%)$ of $U$. lactuca, followed by $\alpha$-cellulose (16.6\%). The $\alpha$-CEL content of Ulva sp. dead biomass was higher than those obtained for U. prolifera, $19.4 \% \alpha$-cellulose, and $14.4 \%$ hemicellulose (Li et al. 2016), or U. pertusa Kjellmann, with $6.7 \%$ cellulose and $16.8 \%$ hemicellulose (Choi et al. 2013).

Table 2. Chemical Characterization of Ulva sp. and Comparison with Other Materials

\begin{tabular}{|c|c|c|c|c|}
\hline \multirow{2}{*}{ Parameter } & \multicolumn{2}{|c|}{ Ulva sp. } & Rhizoclonium sp. (alga) & $\begin{array}{c}\text { C. winterianus } \\
\text { (grass) }\end{array}$ \\
\cline { 2 - 4 } & Average & SD & & 21.5 \\
\hline HWS (\%) & 33.4 & 1.67 & 34.6 & 28.2 \\
\hline $1 \%$ SS (\%) & 29.8 & 0.47 & 36.3 & 6.31 \\
\hline EBE (\%) & 3.8 & 0.47 & 9.43 & 8.2 \\
\hline ASH (\%) & 19.8 & 2.76 & 15.9 & 63.5 \\
\hline HOL (\%) & 47.8 & 4.63 & 44.1 & 38.1 \\
\hline a-CEL (\%) & 40.7 & 3.02 & - & 25.1 \\
\hline KLAS (\%) & 7.9 & 0.65 & 3.8 & Jiménez et al. 2007 \\
\hline Source & This work & Chao et al. 1999 & Sharma et al. 2018 & \\
\hline
\end{tabular}

The low level of Klason-positive (acid insoluble) compounds detected was remarkable in comparison with agricultural residues or wood sources, which are usually around $20 \%$ to $30 \%$ in lignin (Jiménez et al. 2008), and very similar to the amounts reported 
for U. prolifera, 9.4\% (Li et al. 2016), or U. reticulata (Yoza and Masutani 2013). While Li et al. (2016) referred to the acid insoluble material as lignin, it is unlikely that algae could contain such high amounts of that heteropolymer, as they generally lack lignified cell walls (Martone et al. 2009). In any case, the low amount of hydrolysis-resistant compound makes Ulva a structurally fragile material (Lee et al. 2014) and therefore easily degradable during pulping, requiring much less energy and alkali charge than softwood, and less than hardwoods and common agricultural residues (Jimenez et al. 2008; Sharma et al. 2018).

\section{Characterization of Paper Sheets}

Table 3 shows the values of the properties of the handsheets obtained after alkaline and hydrogen peroxide treatments and refining of the algal biomass. The average standard deviation (SD) is reported, showing low random errors for all tests. The highest value of tear index obtained $\left(30.48 \mathrm{mN} \mathrm{m}^{2} / \mathrm{g}\right)$ was elevated compared with the paper sheets formed with bleached hardwood and even some softwood kraft pulps, and it was also high when it was compared with a non-wood raw material such as cotton stalks or vine shoots (Jiménez et al. 2007). Moreover, burst resistance was higher than many other pulps from vegetal residues such as rice straw, palm oil tree, or Leucaena (López et al. 2008; Rodríguez et al. 2008; Alriols et al. 2009). These results were in concordance with other reports where the mechanical properties of materials drastically benefited from the combination of conventional fibers and algal biomass (Seo et al. 2010; Khalil et al. 2017).

Table 3. Physical Properties of the Paper Sheets (50\% Ulva sp. / 50\% Pinus pinaster)

\begin{tabular}{|c|c|c|c|c|c|}
\hline Assay & $\begin{array}{c}\mathrm{TI} \\
\left(\mathrm{mN} \mathrm{m}^{2} / \mathrm{g}\right)\end{array}$ & $\begin{array}{l}\mathrm{BL} \\
(\mathrm{m})\end{array}$ & $\begin{array}{l}\mathrm{ST} \\
(\%)\end{array}$ & $\begin{array}{c}\text { BR } \\
(k N / g)\end{array}$ & $\begin{array}{c}\mathrm{B} \\
(\%)\end{array}$ \\
\hline 1 & 24.54 & 2851 & 2.14 & 2.11 & 46.2 \\
\hline 2 & 29.32 & 2999 & 2.21 & 2.57 & 58.4 \\
\hline 3 & 26.14 & 2950 & 2.18 & 2.40 & 57.0 \\
\hline 4 & 22.59 & 2536 & 1.95 & 1.77 & 53.3 \\
\hline 5 & 19.94 & 2439 & 1.86 & 1.60 & 58.4 \\
\hline 6 & 30.48 & 3163 & 2.30 & 2.66 & 40.2 \\
\hline 7 & 28.35 & 2975 & 2.20 & 2.46 & 37.4 \\
\hline 8 & 22.39 & 2549 & 1.97 & 1.92 & 40.2 \\
\hline 9 & 19.85 & 2486 & 1.88 & 1.65 & 37.6 \\
\hline 10 & 23.59 & 2830 & 2.12 & 2.06 & 54.1 \\
\hline 11 & 24.96 & 2866 & 2.17 & 2.21 & 39.2 \\
\hline 12 & 27.31 & 2983 & 2.20 & 2.51 & 46.3 \\
\hline 13 & 20.33 & 2515 & 1.92 & 1.73 & 46.3 \\
\hline 14 & 25.72 & 2892 & 2.16 & 2.34 & 47.6 \\
\hline 15 & 23.62 & 2834 & 2.13 & 2.04 & 48.4 \\
\hline
\end{tabular}

Chao et al. (2000) found that handsheets made from the red algae Rhizoclonium generally lacked bursting, tearing, and folding strengths (due to the morphological characteristics of the algal strands), but the proper combination with softwood pulp increased the tensile breaking length, tearing index, burst index, and the folding endurance at levels comparable to a typical kraft pulp. More interestingly, the addition of algal biomass from the municipal wastewater treatment to a conventional paper pulp enhances 
the mechanical strength of the latter (Ververis et al. 2007). The increase of breaking length is attributed to the elevated proportion of proteins and its combination with chitin, which acts as a natural binding agent. The results in this work agree with other studies reporting a loss of whiteness (Ververis et al. 2007) as the complete removal of chlorophylls, which show high absorbance of blue and red light even at very small concentrations, is unfeasible.

All experimental data presented in Table 3 were fitted to a second-degree polynomial model as described above. Equations 4 through 8 were attained. The regression considered the five independent variables. Statistically significant terms of the polynomial model were selected with the double standard of having a value of Snedecor's F and Student's t higher than 4 and 2 respectively. These statistical results, together with the values of $\mathrm{R}^{2}$ (Eq. 4-8) being close to 1 , establish a good functional relationship between input and output model parameters. The insignificant lack-of-fit implies that the regression models are well fit (Anupam et al. 2018).

$$
\begin{array}{lc}
T I=24.146+1.26 X S-0.445 X P+3.65 X R-0.458 X P R+0.694 X S^{2} & R=0.997 \\
B L=2854.689+45.476 X S-28.581 X P+254.433 X R-95.073 X R^{2} & R=0.993 \\
S T=2.144+0.151 X R-0.077 X R^{2} & R=0.964 \\
B R=2.135+0.111 X S-0.005 X P+0.393 X R & \\
B=47.375+8.663 X P-1.145 X S P & R=0.995
\end{array}
$$

$$
R=0.984
$$

In Eq. 4, the coefficients of $X_{S}$ and $X_{R}$ have a greater influence on the tear index, that is, it gradually increases with an increase of the refining and soda variables. However, it is clearly more influenced by refining (Fig. 1a), probably due to a good hydration of the fibers (more flexible after refining) resulting in its swelling, increasing its specific surface and therefore the contact points (Seth 1999; Hubbe et al. 2007). With respect to the hydrogen peroxide concentration (Fig. 1b), the influence is barely noticeable. Similarly, the Brassica napus pulps studied by Aguado et al. (2015) and Moral et al. (2017) showed gradual variations in the tear rate when revolutions of the PFI mill were increased.

The second-degree polynomial equation obtained by regression (Eq. 5) reveals that the response variable breaking length was also more influenced by refining than by the concentration of soda. This may be due to the preservation of the natural fiber strength during pulping, as potential weak points in the sheets were minimized by a good removal of non-fibrous elements with little damage to carbohydrates. Then, the internal and external fibrillation caused by refining resulted in higher tensile resistance, without the drawbacks of fiber shortening that hardwoods usually suffer (Fig. 2).

Stretch was only influenced by refining (Eq. 6), and there was an increase in this response variable and elongation, reaching its maximum value $(2.3 \%$, Table 2$)$ at the maximum value of PFI revolutions (5000). However, burst index was not only influenced by refining but also by the amount of soda, which had a remarkable contribution (Eq. 7). Fiber length and the generation of bonds between the fibers (pine and Ulva sp.) play a strong hand in this type of test, which suggests a larger contact surface in addition to a 
greater number of interfibril interactions with the increase of the number of revolutions. Finally, as expected, peroxide concentration was the parameter that impacted whiteness the most (Eq. 8) due to the generation of species responsible for the oxidation of the chromophores (Abdel-Halim and Al-Deyab 2013).

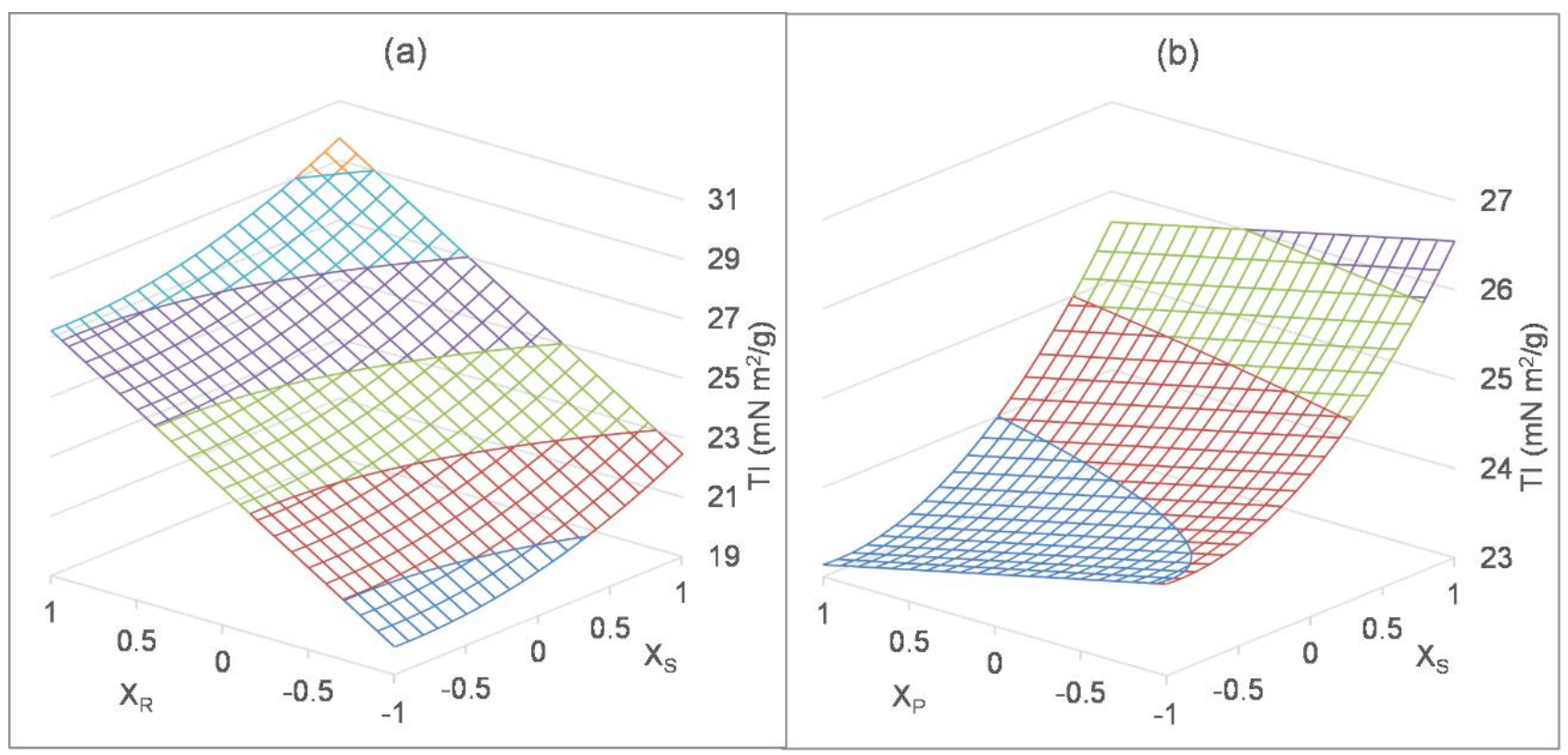

Fig. 1. Response surfaces for the tear index with a) refining and soda concentration; b) hydrogen peroxide and soda concentration; in any case, the normalized values of other independent variables are set at 0

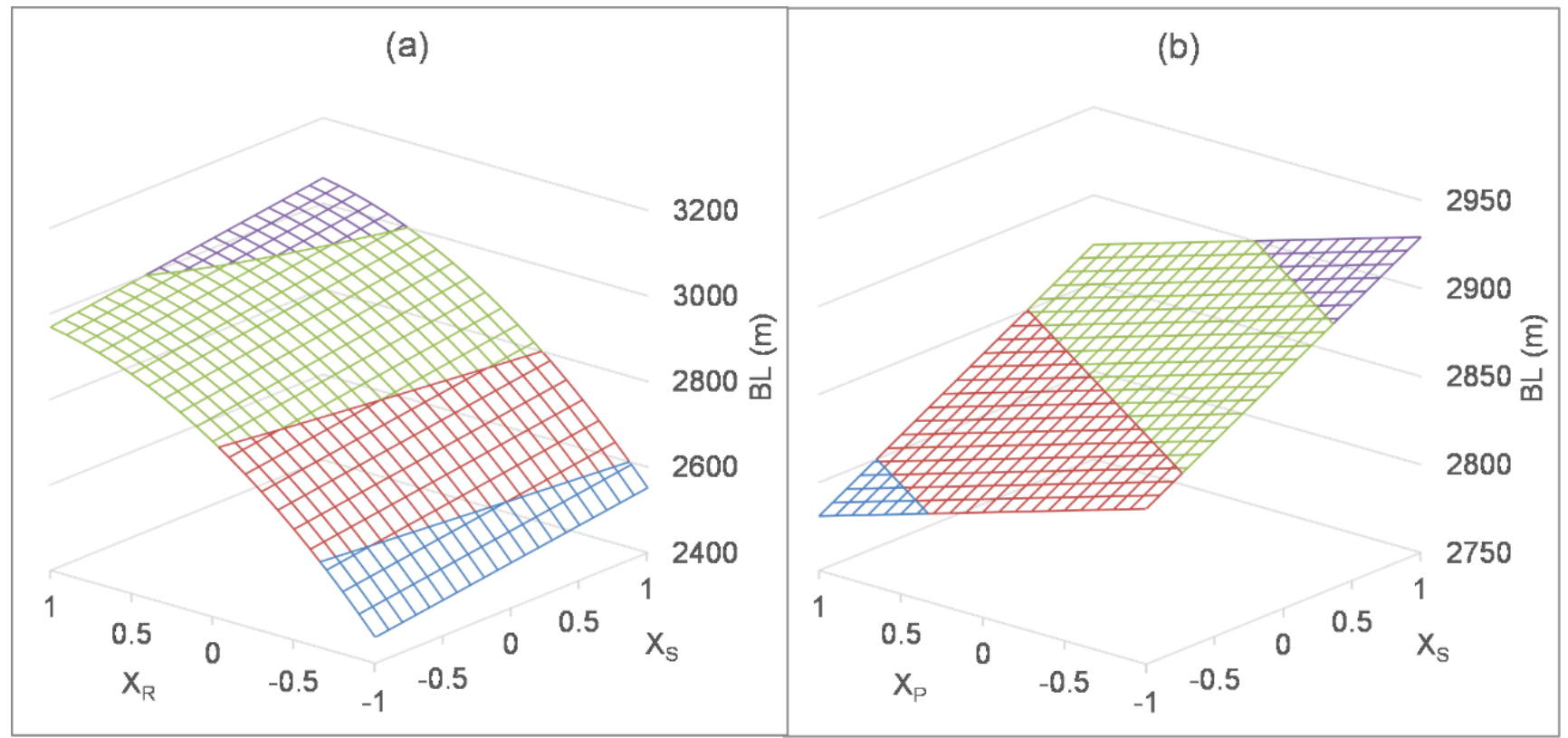

Fig. 2. Response surfaces for the breaking length with a) refining and concentration of soda; b) concentration of peroxide and concentration of soda; in any case, the normalized values of other independent variables are set at 0 


\section{CONCLUSIONS}

1. Chemical characterization of residues of Ulva sp. revealed high abundance of holocellulose (47.8\%), mainly $\alpha$-cellulose, while the percentage of acid-insoluble material $(7.9 \%)$ was low in comparison with conventional, lignin-containing fiber sources.

2. This green seaweed was deemed a promising raw material for its use in papermaking due to its ease of processing, consequently needing a relatively short pulping time, low consumption of energy and low concentration of chemical reagents $\left(90{ }^{\circ} \mathrm{C}, 60 \mathrm{~min}\right.$, and $0.06 \mathrm{~g}$ to $0.1 \mathrm{~g}$ of $\mathrm{NaOH}$ per $\mathrm{g}$ of material).

3. Pulps from Ulva sp. combined with Pinus pinaster provided paper sheets with good physical properties, even surpassing the tear resistance of softwood fibers alone, and thus they should be considered when in search of new alternative sources of fibers for papermaking.

\section{ACKNOWLEDGMENTS}

The authors are grateful to Pablo de Olavide University for the financial support.

\section{REFERENCES CITED}

Abd Hamid, S. B., Chowdhury, Z. Z., and Karim, Md. Z. (2014). "Catalytic extraction of microcrystalline cellulose (MCC) from Elaeis guineensis using central composite design (CCD)," BioResources 9(4), 7403-7426. DOI: 10.15376/biores.9.4.7403-7426

Abdel-Halim, E. S., and Al-Deyab, S. S. (2013). "One-step bleaching process for cotton fabrics using activated hydrogen peroxide," Carbohyd. Polym. 92(2), 1844-1849. DOI: 10.1016/j.carbpol.2012.11.045

Aguado, R., Moral, A., Mutjé, P., and Tijero, A. (2015). "Rapeseed stalks for papermaking: Studies on pulping, refining and dewatering," Cell. Chem. Technol. 49(9), 833-839. DOI: 10.17605/osf.io/2w6g7

Ahlgren, P. A., and Goring, D. A. I. (1971). "Removal of wood components during chlorite delignification of black spruce," Can. J. Chem. 49(8), 1272-1275. DOI: 10.1139/v71-207

Alriols, M. G., Tejado, A., Blanco, M., Mondragón, I., and Labidi, J. (2009). "Agricultural palm oil tree residues as raw material for cellulose, lignin and hemicelluloses production by ethylene glycol pulping process," Chem. Eng. J. 148(1), 106-114. DOI: $10.1016 /$ j.cej.2008.08.008

Anupam, K., Deepika, Swaroop, V., and Lal, P. S. (2018). “Antagonistic, synergistic and interaction effects of process parameters during oxygen delignification of Melia dubia kraft pulp," J. Clean. Prod. 199, 420-430. DOI: 10.1016/j.jclepro.2018.07.125

Baweja, P., Kumar, S., Sahoo, D., and Levine, I. (2016). "Biology of seaweeds," in: Seaweed in Health and Disease Prevention, Academic Press, Cambridge, MA. DOI: 10.1016/B978-0-12-802772-1.00003-8

Chao, K.-P., Su, Y.-C., and Chen, C.-S. (1999). "Chemical composition and potential for utilization of the marine alga Rhizoclonium sp.," J. Appl. Phycol. 11, 525-533. DOI: 10.1023/A:1008142609914 
Chao, K.-P., Su, Y.-C., and Chen, C.-S. (2000). "Feasibility of utilizing Rhizoclonium in pulping and papermaking," J. Appl. Phycol. 12, 53-62. DOI:

10.1023/A:1008166815023

Choi, W.-Y., Kang, D.-H., and Lee, H.-Y. (2013). "Enhancement of the saccharification yields of Ulva pertusa Kjellmann and rape stems by the high-pressure steam pretreatment process," Biotechnol. Bioproc. E. 18(4), 728-735. DOI: 10.1007/s12257013-0033-x

Dawes, C., Chan, M., Chinn, R., Koch, E. W., Lazar, A., and Tomasko, D. (1987). "Proximate composition, photosynthetic and respiratory responses of the seagrass Halophila engelmannii from Florida," Aquat. Bot. 27(2), 195-201, DOI: 10.1016/0304-3770(87)90067-2

Hubbe, M. A., Venditti, R. A., and Rojas, O. J. (2007). "What happens to cellulosic fibers during papermaking and recycling? A review," BioResources 2(4), pp. 739-788. DOI: 10.15376/biores.2.4.739-788

ISO TC/6 (2011). "ISO standards collection on CD-ROM. Paper, board and pulps," International Organization for Standardization, Geneva, Switzerland.

ISO 1924-2 (1992). "Paper and board -- Determination of tensile properties -- Part 1: Constant rate of loading method," International Organization for Standardization, Geneva, Switzerland.

ISO 1974 (2012). "Paper -- Determination of tearing resistance -- Elmendorf method," International Organization for Standardization, Geneva, Switzerland.

ISO 2470-1 (2009). "Paper, board and pulps -- Measurement of diffuse blue reflectance factor -- Part 1: Indoor daylight conditions (ISO brightness)," International Organization for Standardization, Geneva, Switzerland.

ISO 2758 (2014). "Paper -- Determination of bursting strength," International Organization for Standardization, Geneva, Switzerland.

ISO 5269-1 (2005). "Pulps - Preparation of laboratory sheets for physical testing - Part 1: Conventional sheet-former method," International Organization for Standardization, Geneva, Switzerland.

Jiménez, L., Pérez, A., de la Torre, M. J., Moral, A., and Serrano, L. (2007). "Characterization of vine shoots, cotton stalks, Leucaena leucocephala and Chamaecytisus proliferus, and of their ethyleneglycol pulps," Bioresource Technol. 98(18), 3487-3490, DOI: 10.1016/j.biortech.2006.11.009

Jiménez, L., Rodríguez, A., Pérez, A., Moral, A., and Serrano, L. (2008). “Alternative raw materials and pulping process using clean technologies," Ind. Crop. Prod. 28(1), 1116. DOI: 10.1016/j.indcrop.2007.12.005

Jmel, M. A., Messaoud, G. B., Marzouki, M. N., Mathlouthi, M., and Smaali, I. (2016). "Physico-chemical characterization and enzymatic functionalization of Enteromorpha sp. cellulose," Carbohydr. Polym. 135, 274-279, DOI: 10.1016/j.carbpol.2015.08.048

Khalil, H. P. S. A., Tye, Y. Y., Chow, S. T., Saurabh, C. K., Paridah, T., Dungani, R., and Syakir, M. I. (2017). "Cellulosic pulp fiber as reinforcement materials in seaweedbased film," BioResources 12(1), 29-42. DOI: 10.15376/biores.12.1.29-42

Khiari, R., Mhenni, M. F., Belgacem, M. N., and Mauret, E. (2010). "Chemical composition and pulping of date palm rachis and Posidonia oceanica - A comparison with other wood and non-wood fibre sources," Bioresource Technol. 101(2), 775-780, DOI: 10.1016/j.biortech.2009.08.079

Kim, J., and Ha, H. H. (2015). "Hydrothermal pretreatment of Ulva pertusa kjellman using microwave irradiation for enhanced enzymatic hydrolysis," Korean Chem. Eng. Res. 53(5), 570-575, DOI: 10.9713/kcer.2015.53.5.570 
Kiran, E., Tekst, I., Güven, K.C., Güler, E., and Güner, H. (1980). "Studies on seaweeds for paper production," Bot. Mar. 23 (3), 205-207.

Knoshaug, E. P., Shi, B., Shannon, T. G., Mleziva, M. M., and Pienkos, P. T. (2013). "The potential of photosynthetic aquatic species as sources of useful cellulose fibers -A review," J. Appl. Phycol. 25(4), 1123-1134. DOI: 10.1007/s10811-012-9958-2

Lakshmi, D. S., Trivedi, N., and Reddy, C. R. K. (2016). "Synthesis and characterization of seaweed cellulose derived carboxymethyl cellulose," Carbohyd. Polym. 157, 16041610. DOI: 10.1016/j.carbpol.2016.11.042

Lee, S. Y., Chang, J. H., and Lee, S. B. (2014). "Chemical composition, saccharification yield, and the potential of the green seaweed Ulva pertusa," Biotechnol. Bioproc. E. 19(6), 1022-1033. DOI: 10.1007/s12257-014-0654-8

Li, Y., Cui, J., Zhang, G., Liu, Z., Guan, H., Hwang, H., Aker, W. G., and Wang, P. (2016). "Optimization study on the hydrogen peroxide pretreatment and production of bioethanol from seaweed Ulva prolifera biomass," Bioresource Technol. 214, 144149. DOI: 10.1016/j.biortech.2016.04.090

López, F., García, M. M., Yánez, R., Tapias, R., Fernández, M., and Díaz, M. J. (2008). "Leucaena species valoration for biomass and paper production in 1 and 2 year harvest," Bioresource Technol. 99(11), 4846-4853. DOI: 10.1016/j.biortech.2007.09.048

Martone, P. T., Estevez, J. M., Lu, F., Ruel, K., Denny, M. W., Somerville, C., and Ralph, J. (2009). "Discovery of lignin in seaweed reveals convergent evolution of cell-wall architecture," Curr. Biol. 19(2), 169-175. DOI: 10.1016/j.cub.2008.12.031

Michalak, I. (2018). "Experimental processing of seaweeds for biofuels," WIREs Energy Environ. 7(3), 288. DOI: 10.1002/wene.288

Mihranyan, A., Nyholm, L., Garcia Bennett, A. E., and Strømme, M. (2008). “A novel high specific surface area conducting paper material composed of polypyrrole and Cladophora cellulose," J. Phys. Chem. B 112(39), 12249-12255. DOI: $10.1021 /$ jp805123w

Moral, A., Aguado, R., Tijero, A., Tarrés, Q., Delgado-Aguilar, M., and Mutjé, P. (2017). "High-yield pulp from Brassica napus to manufacture packaging paper," BioResources 12(2), 2792-2804. DOI: 10.15376/biores.12.2.2792-2804

Mukherjee, P., and Keshri, J. P. (2019). "A comparative biomass compositional analysis of five algal species from the Paddy Fields of Burdwan District, West Bengal, India, to determine their suitability for handmade paper pulp formulation," Waste Biomass Valori. 10(2), 327-340. DOI: 10.1007/s12649-017-0053-4

Nicolucci, C., di Brenta, C., and Achille, L. (1995). Italy. Patent No 5,472,569.

Nicolucci, C., di Brenta, C., and Achille, L. (1996). Italy. Patent No 5,576, 275.

Olsson, H., Carlsson, D. O., Nyström, G., Sjödin, M., Nyholm, L., and Strømme, M. (2012). "Influence of the cellulose substrate on the electrochemical properties of paper-based polypyrrole electrode materials," J. Mater. Sci. 47(13), 5317-5325. DOI: 10.1007/s10853-012-6418-y

Rajkumar, R., Yaakob, Z., and Takriff, M. S. (2014). "Potential of the micro and macro algae for biofuel production: A brief review," BioResources 9(1), 1606-1633. DOI: 10.15376/biores.9.1.1606-1633

Rodríguez, A., Moral, A., Serrano, L., Labidi, J., and Jiménez, L. (2008). "Rice straw pulp obtained by using various methods," Bioresource Technol. 99(8), 2881-2886, DOI: $10.1016 /$ j.biortech.2007.06.003

Rupérez, P. (2002). "Mineral content of edible marine seaweeds," Food Chem. 79(1), 23 26. DOI: 10.1016/S0308-8146(02)00171-1 
Seo, Y.-B., Lee, Y.-W., Lee, C.-H., and You, H.-C. (2010). "Red algae and their use in papermaking," Bioresource Technol. 101(7), 2549-2553. DOI:

10.1016/j.biortech.2009.11.088

Seth, R. S. (1999). "Beating and refining response of some reinforcement pulps," Tappi J. 82(3), 147-155.

Sharma, N., Godiyal, R. D., Bhawana, Thapliyal, B. P., and Anupam, K. (2018). "Pulping and bleaching of hydro distillation waste of citronella grass (Cymbopogon winterianus Jowitt) for papermaking," Waste Biomass Valor. 9(3), 409-419. DOI: 10.1007/s12649-016-9791-y

TAPPI T203 cm-09 (2009). "Alpha-, beta- and gamma-cellulose in pulp," TAPPI Press, Atlanta, GA.

TAPPI T204 cm-17 (2017). "Solvent extractives of wood and pulp," TAPPI Press, Atlanta, GA.

TAPPI T207 cm-08 (2008). "Water solubility of wood and pulp," TAPPI Press, Atlanta, GA.

TAPPI T211 sp-11 (2011). "Ash in pulp, paper and paperboard: Combustion at $525{ }^{\circ} \mathrm{C}$," TAPPI Press, Atlanta, GA.

TAPPI T222 om-15 (2015). "Acid-insoluble lignin in wood and pulp," TAPPI Press, Atlanta, GA.

TAPPI T264 cm-07 (2007). "Preparation of wood for chemical analysis," TAPPI Press, Atlanta, GA.

Ververis, C., Georghiou, K., Danielidis, D., Hatzinikolaou, D. G., Santas, P., Santas, R., and Corleti, V. (2007). "Cellulose, hemicelluloses, lignin and ash content of some organic materials and their suitability for use as paper pulp supplements," Bioresource Technol. 98(2), 296-301. DOI: 10.1016/j.biortech.2006.01.007

Yaich, H., Garna, H., Besbes, S., Paquot, M., Richel, A., Blecker, C., and Attia, H. (2011). "Chemical composition and functional properties of Ulva lactuca seaweed collected in Tunisia," Food Chem. 128(4), 895-901. DOI: 10.1016/j.foodchem.2011.03.114

Yaich, H., Garna, H., Bchir, B., Besbes, S., Paquot, M., Richel, A., Blecker, C., and Attia, H. (2015). "Chemical composition and functional properties of dietary fibre extracted by Englyst and Prosky methods from the alga Ulva lactuca collected in Tunisia," Algal Res. 9, 65-73. DOI: 10.1016/j.algal.2015.02.017

Yoza, B. A., and Masutani, E. M. (2013). "The analysis of macroalgae biomass found around Hawaii for bioethanol production," Environ. Technol. 34(13-14), 1859-1867. DOI: $10.1080 / 09593330.2013 .781232$

Article submitted: April 8, 2019; Peer review completed: June 16, 2019; Revised version received: June 21, 2019; Accepted: June 22, 2019; Published: July 9, 2019.

DOI: 10.15376/biores.14.3.6851-6862 